Бісмак О. Ефективність застосування реабілітаційних заходів після нейрохірургічного відновлення цілісності пошкоджених периферичних нервів верхньої кінцівки. Теорія і методика фрізичного виховання і спорту. 2020; 1: 55-60 DOI: $10.32652 /$ tmfvs.2020.1.55-60

\title{
ЕФЕКТИВНІСТЬ ЗАСТОСУВАННЯ РЕАБІЛІТАЦІЙНИХ ЗАХОДІВ ПІСЛЯ НЕЙРОХІРУРГІЧНОГО ВІДНОВЛЕННЯ ЦІЛІСНОСТІ ПОШКОДЖЕНИХ ПЕРИФЕРИЧНИХ НЕРВІВ ВЕРХНЬОЇ КІНЦІВКИ
}

\author{
Олена Бісмак \\ Національний університет фізичного виховання і спорту України, Київ, Україна
}

\begin{abstract}
Анотація. Травматичні невропатії - найбільш поширена група захворювань периферичних нервів. У статті розглянуто ефективність реабілітаційних заходів після нейрохірургічного відновлення цілісності пошкоджених периферичних нервів верхньої кінцівки. Мета. Оцінити ефективність застосування технології реабілітаційних заходів у хворих після нейрохірургічного відновлення цілісності пошкоджених периферичних нервів верхньої кінцівки. Методи. Теоретичні (аналіз та узагальнення даних літературних джерел та мережі Інтернет), антропометричні (гоніометрія, динамометрія), електронейроміографія (ЕНМТ). Результати. При первинному обстеженні було виявлено, що у більшості пацієнтів спостерігалися знижені показники обсягу рухів у суглобах та сили м'язів в ураженій кінцівці. За результатами ЕНМГ відмічалося зниження швидкості поширення збудження як моторної, так і сенсорної реакції в усіх пошкоджених нервах та амплітуди М-відповіді, що вказувало на травмування нервової тканини. Реабілітаційна технологія в основній групі пацієнтів включала засоби і методи кінезитерапії, вправи у воді, масаж, ортезування, кінезитейпування, методику ПНФ, нейродинамічні техніки. Для відновлення захоплень пошкодженої руки і активності в повсякденному житті використовували заняття на ерготерапевтичному тренажері ARAT, дзеркальну терапію, СIMT-терапію. У пацієнтів контрольної групи застосовували стандартні реабілітаційні заходи. При повторному обстеженні у результаті застосування сучасних реабілітаційних заходів ми виявили достовірну позитивну динаміку антропометричних та нейрофізіологічних показників у пацієнтів обох груп, проте в основній групі більшість зазначених показників були достовірно кращими. Запропонована технологія реабілітаційних заходів у хворих з пошкодженнями периферичних нервів верхніх кінцівок дозволяє оптимізувати призначення засобів фрізичної терапії та ерготерапії, які спрямовані на відновлення втрачених фрункцій кінцівки.
\end{abstract}

Ключові слова: реабілітаційні заходи, невропатія, травма, пацієнт, верхня кінцівка.

\section{Olena Bismak
EFFICIENCY OF USING REHABILITATION MEASURES AFTER NEUROSURGICAL RESTORATION OF INTEGRITY OF THE UPPER EXTREMITY DAMAGED PERIPHERAL NERVES

\begin{abstract}
Traumatic neuropathies are the most common group of peripheral nerve diseases. The article considers the effectiveness of rehabilitation measures after neurosurgical restoration of the integrity of the upper extremity damaged peripheral nerves. Objective. To evaluate the effectiveness of the technology of rehabilitation measures in patients after neurosurgical restoration of the integrity of the upper extremity damaged peripheral nerves. Methods. Theoretical (analysis and generalization of data from literature sources and the Internet), anthropometric (goniometry, dynamometry), electroneuromyography (ENMG). Results. Initial examination demonstrated a decrease in the range of motions in the joints and muscle strength of the affected limb im most patients. According to the results of ENMG, there was a decrease in the rate of excitation propagation of both motor and sensory responses in all damaged nerves and the amplitude of the M-response, which indicated nervous tissue injury. Rehabilitation technology in the main group of patients included means and methods of kinesitherapy, exercises in water, massage, orthoses, kinesitherapy, PNF technique, neurodynamic techniques. To restore the grips of the injured hand and activity in everyday life exercises on ergotherapy simulator ARAT, mirror therapy, CIMT-therapy were used. Standard rehabilitation measures were applied for patients of the control group. Upon re-examination as a result of modern rehabilitation measures, we found a significant positive dynamics of anthropometric and neurophysiological parameters in patients of both groups, but in the main group most of these indices were significantly better. The proposed technology of rehabilitation measures in patients with damage to the peripheral nerves of the upper extremities allows to optimize the appointment of physical therapy and ergotherapy aimed at restoring lost limb functions.
\end{abstract}

Keywords: rehabilitation measures, neuropathy, injury, patient, upper extremity. 
Вступ. За даними різних авторів, травматичні невропатії є однією з найбільш поширених груп захворювань периферичних нервів [2, 6]. Технічний прогрес, поява нових професій, які вимагають тривалої роботи за комп'ютером, високі темпи урбанізації сучасного суспільства, збільшення природних катаклізмів і техногенних аварій, локальних військових конфліктів і дорожньо-транспортних пригод, а також поява нових екстремальних видів спорту обумовлюють щорічне неухильне зростання кількості пацієнтів 3 ушкодженнями периферичних нервів [3]. Як свідчать дані Bceсвітньої організації охорони здоров'я, зростання травм периферичних нервів за рік становить близько $2 \%$ [7].

Щорічно в Україні проведення операцій з приводу травм периферичних нервів потребують від 2,5 до 4 тис. чоловік [4]. При цьому близько $45 \%$ пошкоджень нервів припадає на найбільш активну вікову групу - від 21 до 55 років [5]. Такі травми практично в 65 \% випадків призводять до тривалої втрати працездатності з високою частотою інвалідизації постраждалих [5]. Травми нервів верхньої кінцівки займають перше місце у загальній структурі травматизму периферичних нервів.

Основний метод лікування цієї категорії пацієнтів - хірургічний. На думку ряду авторів, на підвищення ефективності хірургічного лікування багато в чому впливають засоби фізичної терапії та ерготерапії, які повинні бути невід'ємною частиною комплексного відновного лікування пацієнтів 3 наслідками травматичних уражень нервів верхньої кінцівки [4].

На сьогодні має місце потреба у розробці i впровадженні ефективної реабілітаційної системи, яка б включала програми фізичної терапії та ерготерапії, диференційовані залежно від анатомічної локалізації травми, рівня та ступеня ураження нерва верхньої кінцівки, виду хірургічного втручання, функціонального стану нервово-м'язового апарату після операції, віку пацієнта та інших факторів.

Відомо, що основним методом лікування при травматичних невропатіях верхньої кінцівки є хірургічне втручання. Застосування мікрохірургічної техніки, широко впровадженої в медицині в останні десятиріччя, привело до суттєвого поліпшення результатів хірургічного лікування цієї категорії хворих. На думку відомого нейрохірурга I. Б. Третяка, особливістю хірургії периферичних нервів є те, що за однакових за характером ушкоджень нервів можливі застосування найрізноманітніших методів хірургічного лікування: невроліз, зшивання, аутопластика, невротизація нервів, а також відмова від операції та використання медикаментозного лікування [1, 4].

Важливою умовою поліпшення результатів хірургічного лікування хворих 3 травматичними ушкодженнями нервів руки є максимально повне залучення компенсаторних та регенераторних властивостей нервової системи, дослідження факторів, що найбільш суттєво впливають на кінцевий результат, прогнозування цього результату i, залежно від прогнозованого кінцевого результату, відповідного вибору оптимальної хірургічної тактики лікування та післяопераційного відновлення функції верхньої кінцівки засобами фізичної терапії та ерготерапії [8].

Проте, тільки хірургічного чи медикаментозного лікування недостатньо для відновлення працездатності травмованої руки, активності у виконанні побутових дій, самообслуговуванні та професійних обов'язків. До того ж, неможливо відновити якість життя впливом тільки на стан нервової системи, для ефективної життєдіяльності людям 3 травматичними невропатіями потрібно повноцінне володіння таким важливим органом, як рука.

Проблема відновлення функціонального стану верхньої кінцівки та активності у повсякденному житті при ушкодженнях периферичних нервів верхньої кінцівки на сьогодні ще далека від остаточного вирішення. Важливе значення мають реабілітаційні заходи фізіотерапевтичного та ерготерапевтичного характеру.

Мета дослідження - оцінити ефективність застосування технології реабілітаційних заходів у хворих після нейрохірургічного відновлення цілісності пошкоджених периферичних нервів верхньої кінцівки.

Методи дослідження: теоретичні (аналіз та узагальнення літературних даних та мережі $\mathrm{IH}^{-}$ тернет), антропометричні (гоніометрія, динамометрія), електронейрофізіологічні методи (електронейроміографія, враховували М-відповідь та швидкість проведення імпульсів по еферентних та аферентних провідних шляхах), методи математичної статистики, оцінювання результатів проводили за стандартними методиками.

Результати дослідження та їх обговорення. Дослідження проводили на базі ДУ «Інститут нейрохірургії ім. акад. А. П. Ромоданова НАМН України». У дослідженні брали участь 188 пацієнтів 3 травматичними ураженнями плечового сплетіння та магістральних нервів верхньої кінцівки (ліктьовий, серединний, променевий). Усім хворим проводили нейрохірургічне лікування (невроліз, шов нерва, реконструкція нерва, невротизація).

Відомо, що порушення іннервації скелетних м'язів призводить не тільки до порушення рухів, а й до різного ступеня вираженості морфологічних змін. М'язи, позбавлені трофічного впливу нервової системи, поступово атрофуються, зменшуються в об'ємі і перероджуються. Гинуть м'язові волокна - заміщуються жировою і сполучною тканиною. При пальпації м’язів відмічається втрата ними еластичності: вони стають в'ялими або ж щільними на дотик, відмічаються фібрилярні посмикування і зниження сили, збудливості й електричної активності частково або повністю денервованних скелетних м'язів [4, 9, 10]. 
До початку курсу реабілітації нами було проведено аналіз медичних карток та опитування пацієнтів. За результатами проведеного дослідження було виявлено, що середній вік хворих становив $47 \pm 4,8$ року, переважали чоловіки -139 осіб $(73,9 \%)$, жінок - $49(26,1 \%)$ хворих. Серед причин ушкодження нервів хворі називали дорожньо-транспортні пригоди - 43,1 \% випадків, падіння 3 мотоцикла - 22,9 \%, різані, колоті травми $-18,1 \%$, вогнепальні - 7,4 \%, змішані - 8,5 \% випадків. Тривалість 3 моменту отримання травми до операції - від 3-7 днів до 6 місяців.

Наші дослідження показали, що при порушенні трофіки скелетних м'язів відбуваються розлад вегетативних функцій, зміна шкірних покривів: їх блідість або синюшність, сухість шкіри, холодність кінцівок, зміна температури і потовиділення. При пошкодженні рухового апарату, поряд з прогресуючою м'язовою атрофією, можуть виникати різні деформації і контрактури в результаті вторинних сухожильно-зв'язкових змін.

При первинному обстеженні нами було виявлено, що у більшості пацієнтів спостерігалися знижені показники обсягу рухів у суглобах та сили м'язів в ураженій кінцівці. При невропатії серединного нерва ми відмітили значне відхилення від норми показників згинання та розгинання у променево-зап'ястковому суглобі $\left(39,3 \pm 1,5^{\circ}\right.$ та $37,6 \pm 1,7^{\circ}$ відповідно). У потерпілих з ушкодженнями ліктьового нерва спостерігалися рухові порушення у вигляді зниження кута згинання y п'ястково-фалангових суглобах, проксимальних міжфалангових суглобах та дистальних міжфалангових суглобах постраждалої руки. Подібні результати ми отримали й у хворих 3 невропатією променевого нерва (табл. 1).

Відомо, що одним із важких наслідків травматичного ураження нейромоторного апарату верхніх кінцівок є виникнення атрофії та зниження сили м'язів. Ступінь вираженості атрофічних змін у денервованих м'язах залежить від тяжкості травми периферичних нервів та часу, який пройшов 3 моменту хірургічного втручання. При первинному обстеженні ми виявили, що у 54,3 \% пацієнтів сила м'язів ураженої кінцівки була на рівні $9,4 \pm 1,3$ кг, у 45,7\% - 17,2 \pm 0,7 кг, що свідчило про значне відхилення від норми.

Для об'єктивної оцінки результатів відновлення функції пошкодженого нерва верхньої кінцівки використовували також метод електронейроміографії (ЕНМГ). Дослідження та оцінку результатів проводив лікар функціональної діагностики. Аналіз функції нервово-м'язового апарату здійснювали на основі таких показників: швидкість поширення збудження по рухових волокнах нерва (ШР3 моторна, мс), швидкість поширення збудження по чутливих волокнах нерва (ШР3 сенсорна, мс), амплітуда потенціалу дії м'яза або М-відповіді (амплітуда М-відповіді) - відстань
Таблиця 1 - Показники гоніометрії в обстежених пацієнтів до курсу реабілітації $(n=188)$, град.

\begin{tabular}{|l|l|c|c|}
\hline \multicolumn{1}{|c|}{ Нерв } & \multicolumn{1}{|c|}{ Показник } & Норма & M $\pm \mathbf{m}$ \\
\hline \multirow{1}{*}{$\begin{array}{l}\text { Середин- } \\
\text { ний }\end{array}$} & $\begin{array}{l}\text { Згинання кисті у } \\
\text { променево-зап'ястко- } \\
\text { вому суглобі }\end{array}$ & 90 & $39,3 \pm 1,5$ \\
\cline { 2 - 4 } & $\begin{array}{l}\text { Розгинання кисті у } \\
\text { променево-зап'ястко- } \\
\text { вому суглобі }\end{array}$ & 70 & $37,6 \pm 1,7$ \\
\cline { 2 - 4 } & $\begin{array}{l}\text { Пронація передпліччя у } \\
\text { променево-ліктьовому } \\
\text { суглобі }\end{array}$ & 90 & $42,7 \pm 3,4$ \\
\hline ліктьовий & $\begin{array}{l}\text { Згинання у п'ястково- } \\
\text { фалангових суглобах }\end{array}$ & 90 & $37,4 \pm 2,1$ \\
\cline { 2 - 4 } & $\begin{array}{l}\text { Згинання у прокси- } \\
\text { мальних міжфалангових } \\
\text { суглобах }\end{array}$ & 100 & $38,6 \pm 2,4$ \\
\cline { 2 - 4 } & $\begin{array}{l}\text { Згинання у дисталь- } \\
\text { них міжфалангових су- } \\
\text { глобах }\end{array}$ & 45 & $14,6 \pm 1,3$ \\
\hline $\begin{array}{l}\text { промене- } \\
\text { вий }\end{array}$ & $\begin{array}{l}\text { Розгинання кисті у } \\
\text { променево-зап'ястко- } \\
\text { вому суглобі }\end{array}$ & 70 & $34,4 \pm 2,3$ \\
\cline { 2 - 4 } & $\begin{array}{l}\text { Супінація передпліччя у } \\
\text { променево-ліктьовому } \\
\text { суглобі }\end{array}$ & 90 & $31,2 \pm 2,8$ \\
\hline
\end{tabular}

Таблиця 2 - Результати електронейроміографії в обстежених хворих до курсу реабілітації $(\mathrm{n}=188)$

\begin{tabular}{|l|c|c|c|}
\hline \multicolumn{1}{|c|}{ Нерв } & $\begin{array}{c}\text { шп3 } \\
\text { моторна, мс }\end{array}$ & $\begin{array}{c}\text { шп3 } \\
\text { сенсорна, мс }\end{array}$ & $\begin{array}{c}\text { Амплітуда } \\
\text { м-відповіді, мкВ }\end{array}$ \\
\hline Серединний & $33,2 \pm 1,6$ & $36,4 \pm 1,3$ & $3321,1 \pm 17,3$ \\
\hline Ліктьовий & $36,3 \pm 2,3$ & $40,1 \pm 2,6$ & $2401,3 \pm 16,1$ \\
\hline Променевий & $34,8 \pm 2,4$ & $37,5 \pm 3,1$ & $1923,6 \pm 15,3$ \\
\hline
\end{tabular}

від піку негативного відхилення до піку позитивного відхилення потенціалу дії м'яза (в мкВ).

Як видно з таблиці 2, в обстежених пацієнтів за результатами ЕНМГ відмічалися зниження швидкості поширення збудження (ШПЗ) як моторної, так і сенсорної в усіх пошкоджених нервах та амплітуди М-відповіді, що вказувало на травмування нервової тканини.

Первинне обстеження підтвердило наявність рухових та чутливих розладів у пацієнтів. Після проведення первинного обстеження ми рандомізували пацієнтів на дві групи: основну (ОГ) - 95 пацієнтів та групу порівняння (ГП) - 93 пацієнти. 3 метою прискорення регенерації пошкодженого нерва, зменшення атрофії м'язів, профілактики деформацій і контрактур та відновлення функції травмованої руки в цілому для пацієнтів ОГ ми розробили технологію реабілітаційних заходів. Під час розробки технології ми звертали увагу на наявність реабілітаційного потенціалу у хворих, швидкість регенерації ушкоджених нервів, змен- 
Таблиця 3 - Показники гоніометрії пацієнтів після курсу реабілітації, град.

\begin{tabular}{|c|c|c|c|c|}
\hline \multirow[t]{2}{*}{ Нерв } & \multirow[t]{2}{*}{ Показник } & \multirow[t]{2}{*}{ Норма } & $\begin{array}{c}\text { Основна група } \\
(n=95)\end{array}$ & $\begin{array}{c}\text { Група порівнян- } \\
\text { ня }(\mathrm{n}=93)\end{array}$ \\
\hline & & & $M \pm m$ & $M \pm m$ \\
\hline \multirow[t]{3}{*}{ Серединний } & Згинання кисті у променево-зап'ястковому суглобі & 90 & $52,7 \pm 4,6^{\star}$ & $44,6 \pm 2,6$ \\
\hline & Розгинання кисті у променево-зап'ястковому суглобі & 70 & $47,2 \pm 3,4$ & $43,1 \pm 2,9$ \\
\hline & Пронація передпліччя у променево-ліктьовому суглобі & 90 & $59,5 \pm 4,1^{\star}$ & $49,8 \pm 3,1$ \\
\hline \multirow[t]{3}{*}{ Ліктьовий } & Згинання у п'ястково-фалангових суглобах & 90 & $52,4 \pm 3,4^{\star}$ & $46,3 \pm 3,2$ \\
\hline & Згинання у проксимальних міжфалангових суглобах & 100 & $54,3 \pm 3,9^{\star}$ & $47,6 \pm 3,9$ \\
\hline & Згинання у дистальних міжфалангових суглобах & 45 & $24,1 \pm 1,9$ & $18,1 \pm 1,6$ \\
\hline \multirow[t]{2}{*}{ Променевий } & Розгинання кисті у променево-зап'ястковому суглобі & 70 & $61,4 \pm 4,6^{\star}$ & $50,3 \pm 3,6$ \\
\hline & Супінація передпліччя у променево-ліктьовому суглобі & 90 & $63,7 \pm 4,9^{*}$ & $48,9 \pm 3,7$ \\
\hline
\end{tabular}

* p $<0,05$ між показниками основної та групи порівняння

Таблиця 4 - Результати електронейроміографії в обстежених хворих після курсу реабілітації

\begin{tabular}{|c|c|c|c|c|c|c|}
\hline \multirow{2}{*}{ Нерв } & \multicolumn{3}{|c|}{ Основна група, n = 95} & \multicolumn{3}{|c|}{ Група порівняння, $\mathrm{n}=93$} \\
\hline & $\begin{array}{c}\text { ШПз моторна, } \\
\text { мс }\end{array}$ & $\begin{array}{c}\text { ШПЗ сенсорна, } \\
\text { мс }\end{array}$ & $\begin{array}{c}\text { Амплітуда } \\
\text { М-відповіді, мкВ }\end{array}$ & $\begin{array}{c}\text { ШП3 моторна, } \\
\text { мс }\end{array}$ & $\begin{array}{c}\text { ШПЗ сенсорна, } \\
\text { мс }\end{array}$ & $\begin{array}{c}\text { Амплітуда } \\
\text { М-відповіді, мкВ }\end{array}$ \\
\hline Серединний & $44,2 \pm 3,6$ & $61,7 \pm 4,3^{\star}$ & $5463 \pm 19,2$ & $38,8 \pm 2,8$ & $46,2 \pm 3,7$ & $4920 \pm 18,3$ \\
\hline Ліктьовий & $47,1 \pm 3,1^{\star}$ & $46,5 \pm 3,2$ & $4136 \pm 19,4^{\star}$ & $40,6 \pm 2,8$ & $42,6 \pm 2,6$ & $3452 \pm 17,1$ \\
\hline Променевий & $41,3 \pm 3,4$ & $48,5 \pm 3,7$ & $3258 \pm 18,3^{\star}$ & $38,2 \pm 3,1$ & $43,6 \pm 2,9$ & $2341 \pm 16,7$ \\
\hline
\end{tabular}

* p $<0,05$ між показниками основної та групи порівняння

шення больового синдрому, а також враховували психоемоційний стан пацієнтів. Відповідно до цього для кожного періоду відновлення підбирали оптимальні засоби фізичної терапії та ерготерапії.

Для запобігання атрофії, фіброзного переродження денервованних м’язів і збереження їх у можливо кращому стані нами застосовувалися засоби і методи кінезитерапії (пасивні, активні вправи для пошкодженої кінцівки, ізометричні вправи, вправи $з$ предметами, спеціальні вправи для відновлення дрібної моторики тощо), вправи у воді, масаж, ортезування, кінезитейпування, методику ПНФ, нейродинамічні техніки.

Для відновлення захоплень пошкодженої руки й активності в повсякденному житті використовували заняття на ерготерапевтичному тренажері ARAT, дзеркальну терапію, CIMT-терапію.

3 метою диференційованого підходу до розробки програми реабілітаційних заходів для постраждалих весь реабілітаційний процес було розподілено на кілька періодів: іммобілізаційний, ранній постіммобілізаційний, пізній постіммобілізаційний та резидуальний. Щоб реабілітація була ефективною, заняття терапевтичними і фізичними вправами проводили індивідуально з кожним хворим (в іммобілізаційному і ранньому відновлювальному періоді), в інших періодах - малогруповим методом.
У пацієнтів ГП застосовували стандартні реабілітаційні заходи (фізичні вправи, масаж, механотерапія, апаратна фізіотераія).

Курс реабілітації у пацієнтів 3 травматичними невропатіями верхньої кінцівки тривав три місяці. Наприкінці курсу проводили повторне обстеження хворих. Ефективність реабілітаційних заходів оцінювали за змінами сили м'язів ураженої руки та амплітуди рухів у різних суглобах, швидкості регенерації пошкоджених нервів, біоелектричної активності скелетних м'язів.

Технологія реабілітаційних заходів, яку ми розробили для пацієнтів ОГ, сприяла появі і значному збільшенню рухової функції в суглобах ураженої кінцівки залежно від виду і локалізації пошкодження конкретного нерва. Так, при порушенні серединного нерва у 78 \% пацієнтів ОГ значно збільшився кут згинання у променевозап'ястковому суглобі порівняно з хворими ГП і становив 52,7 \pm 4,6 . Достовірне збільшення відмічається також у показниках пронації передпліччя у променево-ліктьовому суглобі у хворих основної групи $(\mathrm{p}<0,05)$.

Необхідно відмітити про достовірне збільшення рухової функції у проксимальних міжфалангових суглобах та супінації передпліччя у променево-ліктьовому суглобі в осіб ОГ порівняно з ГП ( $<0,05)$ (табл. 3). 
Активне застосування вправ на тренажерах сприяло збільшенню сили мязів ушкодженої кінцівки у пацієнтів обох груп, проте в ОГ у 70,5 \% осіб показники динамометрії були на рівні 24,3 \pm $\pm 2,8$ кг, у 29,5 \% - на рівні 29,4 $\pm 2,6$, що значно краще, ніж у ГП (у більшості хворих сила м'язів збільшилася до 21,4 \pm 1,9 кг).

У результаті застосування сучасних реабілітаційних заходів в ОГ швидкість поширення збудження (ШПЗ) по моторних і сенсорних волокнах достовірно збільшилася порівняно з хворими ГП. Збільшення амплітуди М-відповіді також свідчило про кращу регенерацію пошкоджених нервів в осіб ОГ (табл. 4).

Отже, повторне обстеження свідчило про позитивну динаміку антропометричних та нейрофізіологічних показників пацієнтів обох груп, проте в ОГ більшість зазначених показників були достовірно кращими.

Дискусія. Сучасний етап розвитку системи охорони здоров'я ставить перед фахівцями, які займаються проблемами відновлення функції верхньої кінцівки при ушкодженнях периферичних нервів, складне завдання вибору та використання сучасних реабілітаційних заходів. На проблему застосування засобів фізичної терапії та ерготерапії при травматичних невропатіях верхньої кінців- ки звертається увага в багатьох дослідженнях [3, 5]. На думку I. Б. Третяка зі співавт., комплекс реабілітаційних заходів в таких випадках, з одного боку, спрямований на стимуляцію регенераційних процесів, з іншого - не менш важливим завданням реабілітації є примусова стимуляція компенсаторних механізмів [4]. Велике значення має диференційованість реабілітаційних заходів, яка визначається передовсім етіологією і поширеністю ураження нервів, та індивідуальний підхід до реабілітації кожного хворого.

Висновки. Запропонована технологія реабілітаційних заходів у хворих з ушкодженням периферичних нервів верхніх кінцівок дозволяє оптимізувати призначення засобів фізичної терапії та ерготерапії, які спрямовані на відновлення втрачених функцій кінцівки. Ефективність розробленої технології підтверджується покращенням результатів антропометричних та електронейроміографічних показників у пацієнтів основної групи порівняно з групою порівняння.

Перспективи подальших досліджень полягають у вивченні впливу реабілітаційних заходів при поєднаних травмах верхньої кінцівки.

Конфлікт інтересів. Автор заявляє, що відсутній будь-який конфлікт інтересів.

\section{Література}

1. Дивович ГВ, Макарчик АВ, Титенков ВМ. Транспозиции мышц при поражениях плечевого сплетения. Проблемы здоровья и экологии. 2012;7-12.

2. Сидорович РР. Реконструктивные операции мышечной и сухожильно-мышечной транспозиции в реабилитации пациентов с последствиями травматического повреждения плечевого сплетения. Медицина и здравоохранение. Клиническая медицина. 2011;4 (55):79-88.

3. Снытников КЮ, Халяпин ДВ, Бельчинский ВВ, Плетнев АВ, Кочукова МВ. Лечение больных при повреждении нервов. Молодой ученый. 2016;5:234-237. URL https://moluch.ru/archive/109/26546/ (дата обращения: 03.04.2020).

4. Третяк ІБ, Чеботарьова ЛЛ, Третьякова АІ. Діагностика та лікування хворих з ушкодженнями, переважно, верхнього стовбура плечового сплетіння [Електронний ресурс]. Український нейрохірургічний журнал. 2010;3:57. Режим доступу: http:// nbuv.gov.ua/UJRN/Unkhj_2010_3_104.

5. Цимбалюк ВІ, Страфун СС, Гайко ОГ, Гайович ВВ. Концепція відновлення функції кінцівки при травматичному ушкодженні периферичних нервів. Український нейрохірургічний журнал. 2016;3:48-54.

6. Dahlin LB, Wiberg M. Nerve injuries of the upper extremity and hand. EFORT Open Rev. 2017 May;2(5):158170. doi: 10.1302/2058-5241.2.160071.

7. Novak CB, L. Heyde R. Rehabilitation of the Upper Extremity Following Nerve and Tendon Reconstruction: When and How. Semin Plast Surg. 2015 Feb;29(1):73-80. doi: 10.1055/s-0035-1544172.

8. Patterson JM. High ulnar nerve injuries: nerve transfers to restore function. Hand Clin. 2016;32:219-226.

9. Ruijs AC, Jaquet JB, Kalmijn S, Giele H, Hovius SE. Median and ulnar nerve injuries: a meta-analysis of predictors of motor and sensory recovery after modern microsurgical nerve repair. Plast Reconstr Surg. 2005;116:484496.

10. Sandow MJ, McMahon M. Active mobilisation following single cross grasp four-strand flexor tenorrhaphy (Adelaide repair) J Hand Surg Eur 2011;36(6):467-475.

\section{Literature}

1. Divovich GV, Makarchik AV, Titenkov VM. Muscle transpositions in lesions of the humeral plexus. Problemy zdorovya i ekologiyi. 2012;7-12.

2. Sidorovich RR. Reconstructive operations of muscle and tendon-muscle transposition in rehabilitation of patients with the consequences of traumatic injury of the humeral plexus. Meditsina $\mathrm{i}$ zdravookhraneniye. Klinicheskaya meditsina. 2011;4 (55):79-88. 
3. Snytnikov KY, Khalyapin DV, Belchinsky VV, Pletnev AV, Kochukova MV. Treating patients with damaged nerves. Molodoy ucheny. 2016;5:234-237. URL https://moluch.ru/archive/109/26546/ .

4. Tretiak IB, Chebotariova LL, Tretiakova Al. Diagnosis and treatment of patients with injuries, mainly of the upper trunk of the humeral plexus [Electronic resource]. Ukrainskyi neirokhirurhichnyi zhurnal. 2010;3:57. Access mode: http:// nbuv.gov.ua/UJRN/Unkhj_2010_3_104.

5. Tsymbaliuk VI, Strafun SS, Hayko OH, Hayovych VV. The concept of restoring limb function in traumatic injury of peripheral nerves. Ukrainskyi neirokhirurhichnyi zhurnal. 2016;3:48-54.

6. Dahlin LB, Wiberg M. Nerve injuries of the upper extremity and hand. EFORT Open Rev. 2017 May;2(5):158170. doi: 10.1302/2058-5241.2.160071.

7. Novak CB, L. Heyde R. Rehabilitation of the Upper Extremity Following Nerve and Tendon Reconstruction: When and How. Semin Plast Surg. 2015 Feb;29(1):73-80. doi: 10.1055/s-0035-1544172.

8. Patterson JM. High ulnar nerve injuries: nerve transfers to restore function. Hand Clin. 2016;32:219-226.

9. Ruijs AC, Jaquet JB, Kalmijn S, Giele H, Hovius SE. Median and ulnar nerve injuries: a meta-analysis of predictors of motor and sensory recovery after modern microsurgical nerve repair. Plast Reconstr Surg. 2005;116:484496.

10. Sandow MJ, McMahon M. Active mobilisation following single cross grasp four-strand flexor tenorrhaphy (Adelaide repair) J Hand Surg Eur 2011;36(6):467-475.

Надійшла 25.02.2020

\section{Інформація про автора}

Бісмак Олена Василівна

https:orcid.org /0000-0002-6495-6170

E-mail: ebismak@gmail.com

Тел.: +380665744953

Національний університет

фрізичного виховання і спорту України,

вул. Фізкультури 1, м. Київ, 03150, Україна

\section{Information about the authors}

Bismak Olena

https:orcid.org /0000-0002-6495-6170

E-mail: ebismak@gmail.com

Тел.: +380665744953

National University

of Ukraine on Physical Education and Sport:

Fizkul'tury str. 1, Kyiv, 03150, Ukraine 